\title{
Failure of filtration operations in the African
}

\author{
N. H. WELSH
}

Department of Ophthalmology, King Edward VIII Hospital, Durban, South Africa

Filtration operations in Negroes and in other heavily-pigmented races have earned a bad reputation for a high rate of failure, but it is difficult to estimate the extent of this failure because it is difficult if not impossible to achieve an adequate follow-up in these cases (McNair, I95I ; Welsh, I969). Iliff (1944) reported a success rate of 23 per cent. with trephine operations and of 50 per cent. with iridencleisis. Berson, Zauberman, Landau, and Blumenthal ( 1969 ), in a series of 1 I 9 African patients, found a success rate of 39 per cent. for trephines, 26 per cent. for Scheie procedures, and 4 per cent. for iridencleisis. Our success rate is also roughly 30 to 50 per cent. (trephine and Scheie operations). In white patients on the other hand, Friedenwald (1950) reported a success rate of 80 to 90 per cent. and Scheie (1962) of more than 90 per cent.

The special problems encountered in Negroes and other dark-skinned patients hav $\hat{\varnothing}$ been attributed to a tendency to develop scar tissue more easily. Friedenwald (1950 stated that a study of eyes enucleated after drainage failures showed more episcleras scarring in the eyes of Negroes than in those of white patients. Luntz and Smith (1960) found pathological episcleral fibrosis to be present in four Negro patients undergoing drainage operations and postulated this as a cause of the glaucoma and thus of the low rate of success. McNair (I95I) sent out a questionnaire to I 25 ophthalmologists in the United States of America concerning chronic simple glaucoma in the Negro. $\mathrm{He}$ concluded that failure of fistulization was due to cicatrization of the bleb which was related to a thick Tenon's capsule which flayed out early. He also mentioned the thicker iris which impinged on the angle and the high percentage of positive Wassermann reactions (29.8 per cent.) with an increased tendency to form inflammatory exudates. The tendency to keloid formation causing fibrosis and adherence of conjunctiva and Tenon's capsule to sclera is generally accepted (Scheie, r 969).

The purpose of this paper is to review those of our filtration operations that failed in order to provide useful practical information on a problem which is no longer a surgical curiosity. Our cases show, on gonioscopic evidence and in a number of re-operations, that the failure of fistulization was due to a localized overgrowth of the external fistulous opening by fibrous tissue coming either from the walls of the scleral opening or from Tenon's capsule. This occurs soon after the operation with no bleb formation and anterior synechiae, though present, are of significance in only a few cases. There is no abnormal episcleral fibrosis preoperatively in the majority of cases and Tenon's capsule is not thickened. Since blebs do not form, the problem of cicatrization of a non-draining bleb did not arise.

Positive Wassermann reactions were only found in 5 per cent. of all the African patients attending the hospital, and do not appear to affect the postoperative results. 


\section{Material and methods}

During a 24-month period (October 1, 1967, to September 30, 1969), 143 drainage operations were performed on cases of chronic open-angle glaucoma in African and Indian patients; 103 of them were lost to follow-up, either because the patient did not return or because the records were not available, so that a correct estimate of success and failure rates is not possible. Of the forty cases which were followed, 28 (29 eyes) showed a sustained increase in intraocular pressure despite medical treatment, and thesc cases form the subject of this paper.

Of these 28 patients, 27 were Africans (Zulu tribe) and one was an Indian. There were fifteen males and thirteen females, and their ages ranged from 21 to 76 years.

The patients were examined particularly for the appearance of the drainage bleb; the gonioscopic appearance of the angle; the presence of synechiae; and the site of the internal opening of the scleral fistula.

The appearance of the external opening of the scleral fistula with or without conjunctival fibrosis was examined in cases in which re-operation was undertaken.

Conjunctival fibrosis was judged to be present if the conjunctiva was adherent to the scleral opening or was obviously blocking it. If the conjunctiva could be separated from the sclera and the scleral opening with ease, no pathological conjunctival fibrosis was judged to be present. The external scleral opening was either patent or so badly blocked by tissue derived from the surrounding sclera or from Tenon's capsule that one had to search for the position of the peripheral iridectomy in order. to find the site of the previous drainage channel.

\section{Results}

Table I shows the operations that were originally performed and the number of eyes that had anterior synechiae. The most significant feature was that only one eye showed a drainage bleb.

Table I Eyes with anterior synechiae and drainage blebs

\begin{tabular}{lcccc}
\hline Original operation & $\begin{array}{l}\text { No. of } \\
\text { eyes }\end{array}$ & & $\begin{array}{l}\text { Anterior } \\
\text { synechiae }\end{array}$ & Bleb \\
Trephine & & & I2 & I \\
Scheie & 15 & & 10 & - \\
Post-sclerectomy & 2 & I & - \\
\hline
\end{tabular}

Table II shows the gonioscopic findings in seventeen eyes which had originally undergone drainage operations that had proved unsuccessful. There were no drainage blebs present. Anterior synechiae were present at the drainage site in fifteen eyes, but were judged to be sufficiently extensive to contribute towards blockage only in five. Scleral tissue blocking the drainage fistula on its inner aspect could be seen in five eyes.

Table II Site of obstruction in seventeen cases of drainage failure not undergoing re-operation

\begin{tabular}{|c|c|c|c|c|c|}
\hline Original operation & $\begin{array}{l}\text { No. of } \\
\text { eyes }\end{array}$ & $\begin{array}{l}\text { Severe } \\
\text { anterior } \\
\text { synechiae }\end{array}$ & Bleb & $\begin{array}{l}\text { Internal } \\
\text { scleral } \\
\text { overgrowth }\end{array}$ & $\begin{array}{l}\text { External } \\
\text { scleral } \\
\text { obstruction }\end{array}$ \\
\hline $\begin{array}{l}\text { Trephine } \\
\text { Scheie } \\
\text { Post-sclerectomy }\end{array}$ & $\begin{array}{l}7 \\
8 \\
2\end{array}$ & $\begin{array}{l}3 \\
2 \\
-\end{array}$ & I & $\begin{array}{l}3 \\
2 \\
-\end{array}$ & $\begin{array}{l}1 \\
4 \\
2\end{array}$ \\
\hline
\end{tabular}


Table III shows the gonioscopic and operative findings in the twelve eyes that underwent a second drainage operation. Anterior synechiae were present in eight, but were con- $\frac{0}{3}$ sidered significant in only one. One eye developed malignant glaucoma with its attendanto complications. The remaining ten eyes all showed blocking of the drainage fistula in the $\vec{F}$ scleral portion, by scleral tissue or by fibrous tissue. It was difficult to assess the origin of this fibrosis but it probably derived from Tenon's capsule. Scleral tissue has little tendency음 to fibroblastic activity (Maumenee, 1967) and the surface of the external scleral opening $\frac{\overline{\bar{N}}}{\mathrm{D}}$ was so effectively closed that in some cases it was difficult to find the site of the original $\mathbb{\Phi}^{\mathbb{R}}$ scleral fistula. Three of the eyes showed conjunctival fibrosis as well as scleral fibrosisin and in one eye the conjunctival fibrosis was marked. However, conjunctival fibrosis $\overrightarrow{0}$ causing blockage was not as significant as one would have expected. In eight eyes, the $\overrightarrow{\vec{\omega}}$ conjunctiva was reflected away from the sclera easily enough, and the drainage fistula $\omega$ was found to be completely overgrown by tissue flush with the sclera. Two of these eyes $\bar{O}$. had shown internal scleral overgrowth gonioscopically, and the scleral canal was occluded by fibrous tissue from its walls.

Table III Site of obstruction in twelve eyes undergoing re-operation

\begin{tabular}{|c|c|c|c|c|c|c|}
\hline \multirow{2}{*}{$\begin{array}{l}\text { Original } \\
\text { operation }\end{array}$} & \multirow{2}{*}{$\begin{array}{l}\text { No. of } \\
\text { eyes }\end{array}$} & \multirow{2}{*}{$\begin{array}{l}\text { Severe } \\
\text { anterior } \\
\text { synechiae }\end{array}$} & \multirow{2}{*}{ Bleb } & \multirow{2}{*}{$\begin{array}{l}\text { Internal } \\
\text { scleral } \\
\text { overgrowth }\end{array}$} & \multicolumn{2}{|c|}{ External obstruction } \\
\hline & & & & & Scleral & Conjunctival \\
\hline Trephine & 7 & - & - & 2 & 6 & 2 \\
\hline Scheie & $5^{*}$ & I & - & - & 2 & $\mathbf{I}$ \\
\hline
\end{tabular}

*One case of Scheie procedure developed malignant glaucoma

Table IV shows three cases in which drainage operations had been performed on bat eyes, but had been unsuccessful in only one. This gave a unique opportunity to compare the gonioscopic appearances in the two eyes. In each eye that was successful, a drainage $\frac{\partial}{0}$ bleb was present and in the eyes that had failed there was no bleb. All eyes showed anterior synechiae and the drainage fistula had been placed anterior to the canal of Schlemm. In the first case, the internal opening of the drainage fistula looked closed, yetö the drainage was successful, and in the other eye, in which the internal opening appeared to be wide open, there was no drainage. Gonioscopic appearances are therefore deceptive, but these cases illustrate that the block in drainage is on the external side of the scleral canal.

Table IV Gonioscopic appearances in three cases of bilateral operation with unilateral failure

\begin{tabular}{|c|c|c|c|c|c|c|}
\hline $\begin{array}{l}\text { Original } \\
\text { operation }\end{array}$ & Eye & $\begin{array}{l}\text { Date of } \\
\text { original } \\
\text { operation }\end{array}$ & $\begin{array}{l}\text { Present } \\
\text { tension } \\
(\mathrm{mm} . \mathrm{Hg})\end{array}$ & Bleb & $\begin{array}{l}\text { Anterior } \\
\text { synechiae }\end{array}$ & Probable site of block \\
\hline Scheie & $\begin{array}{l}\mathbf{R} \\
\mathbf{L}\end{array}$ & $\begin{array}{r}16.4 .68 \\
1.4 .68\end{array}$ & $\begin{array}{l}18 \\
26\end{array}$ & \pm & $\begin{array}{l}+ \\
+\end{array}$ & $\overline{\text { External scleral opening }}$ \\
\hline Trephine & $\underset{\mathrm{L}}{\mathrm{R}}$ & $\begin{array}{r}17 \cdot 3.69 \\
6.6 .69\end{array}$ & $\begin{array}{l}\text { I I } \\
35\end{array}$ & \pm & $\begin{array}{l}+ \\
+\end{array}$ & $\overline{\text { External scleral opening }}$ \\
\hline Scheie & $\begin{array}{l}\mathbf{R} \\
\mathbf{L}\end{array}$ & $\begin{array}{r}9.8 .67 \\
25.8 .67\end{array}$ & $\begin{array}{l}20 \\
30\end{array}$ & \pm & + & $\overline{\text { External scleral opening }}$ \\
\hline
\end{tabular}

\section{Discussion}

Failure of filtration operations has been adequately dealt with in the past. Maumenee $\sigma_{0}^{T}$ (1967) showed that the causes were intraocular (due to lens, iris, or vitreous); scleral 
(narrow drainage cleft or persistence of Descemet's membrane); and extraocular (trauma, haemorrhage, inflammation to flap, foreign material under flap). We have found that all these causes occur in our patients but in the African particularly, the iris, sclera, Tenon's capsule, and conjunctiva react more severely to surgical trauma. What therefore are the differences between the Negro or African and the Caucasian eye? Boles-Carenini, Buten, Spurgeon, and Ascher (1955) found physiologically that there are no differences. They studied the normotensive eyes of 107 white and 97 Negro persons and found that the dynamics of the aqueous humour were equal in both groups and that the intraocular pressure, facility of aqueous outflow, and production of aqueous were also the same. Anatomically, the brown iris in pigmented eyes does not dilate readily and the trabecular tissue shows more pigment on gonioscopic examination. The heavily-pigmented iris shows a tendency to postoperative iritis and adhesions. Considering iris behaviour first, 8o per cent. of our cases showed anterior synechiae. Allen (1966) found anterior synechiae in only four of 34 postoperative drainage cases presumably in whites. Sollom (1969) found that 45 out of 54 cases of Scheie procedures showed anterior synechiae. These have been proved to be unimportant and Sollom found only four cases with a raised intraocular pressure. He related anterior synechiae formation to preoperative anterior chamber depth. In Table IV all three cases showed anterior synechiae whether there was successful drainage or not. Nevertheless, since postoperative iritis and flat anterior chamber are common in our cases, the easily-formed and prominent anterior synechiae may diminish aqueous flow through the scleral fistula, thus affecting bleb formation. Considering then the extraocular factors that lead to failure of drainage, the scleral reaction and Tenon's capsule reaction are much more evident than in white patients. However, at operation, when the conjunctival flap is reflected, we have noted any obvious episcleral fibrosis, and this was found in only one eye in the last forty glaucoma operations. In the other eyes, it was apparent that, even with a long-standing ocular tension of $60 \mathrm{~mm}$. $\mathrm{Hg}$, the conjunctiva was thin and easily reflected with little Tenon's capsule present. Therefore preoperative abnormal episcleral fibrosis can be discounted in most of our glaucoma patients. In addition, the drainage failures occur in the older age groups (over 50 years), since our patients present in the final stages of glaucoma and Tenon's capsule is thin. Then, when drainage fails, it does so early so that a bleb fails to form. Cicatrization of formed blebs with consequent nonabsorption of aqueous is not the problem that we have to deal with. The state of the conjunctiva is also noted during surgery, and again it is usually thin and appears to be normal. At the subsequent operation, the conjunctiva is no more adherent than one would find in Caucasian eyes, but the obstruction appears to come from Tenon's capsule at the scleral edges themselves, since the external fistula has been occluded by fibrous tissue overgrowth. Thus, although Tenon's capsule looks normal, it probably reacts excessively to trauma by providing fibroblasts for the cut scleral edges. Therefore, foreign substances placed subconjunctivally will not maintain long-term filtration unless the scleral canal is kept open. There is some doubt why fistulizing operations should work. DeVoe (195I) felt that it was due to trauma of the uveal tract and to readjustment of the neurovascular system. If the trabecular meshwork is opened up by the fistula, aqueous can pass through the side walls into the canal of Schlemm (Cairns, 1969). Teng, Ghi, and Katzin (1959) suggested that aqueous had a deleterious effect on collagen and worked to prevent fibroblasts forming collagen. Thus the aqueous causes perivascular degeneration by affecting collagen around the blood vessels, and endothelial proliferation then occurs forming drainage channels. It is thus possible that in our African patients failure of drainage is due not to keloid formation but to a failure of aqueous to affect the fibro- 
blasts and collagen tissue. With anterior synechiae formation, insufficient aqueous passes subconjunctivally and its effect is further reduced. Therefore physical methods of impeding fibroblast formation may prove helpful, and the best of these are beta irradiation (Simmons, 1959) and cryothermy to the sclera. In view of these findings, when a drainage operation is performed on an African patient, we attempt to improve the prognosis by the following measures:

The fistula should be made through the trabecular area. No cautery is used, since surface diathermy may cause conjunctiva to adhere to sclera. Deep diathermy will damage the canal of Schlemm through the side of the fistula. A large peripheral iridectomy is performed and surface cryothermy is applied to the sclera surrounding the fistula. Subconjunctival cortisone is injected to control postoperative uveitis.

It may be questioned, however, whether fistula operations with their attendant complications are indicated in African patients, and it was therefore decided to carry out internal trabeculectomy procedures (Cairns, 1968). Forty such operations have so far been performed with a certain amount of success, and the results will be available shortly.

\section{Summary}

Gonioscopic studies of 29 eyes in patients of the heavily-pigmented races (and in twelve of $\vec{\omega}$ these confirmation at operation) have shown that failure of fistulization is due mainly to overgrowth of the external scleral fistula by fibrous tissue derived from the sclera and Tenon's capsule. Anterior synechiae are present in 80 per cent. of cases, filtration blebs do not form, and there is no preoperative abnormality in the episcleral tissues or in Tenon's capsule. Compared with Caucasian eyes, the reaction in Negro or Indian eyes to surgical trauma is more severe. The measures taken to overcome these problems include the use of a large peripheral iridectomy, cryothermy to the bare sclera surrounding the fistula, and subconjunctival cortisone.

I wish to thank Prof. L. Baker, Head of the Department of Surgery, and Dr. H. Wannenburg, Superintendent of King Edward VIII Hospital, for permission to publish these cases.

\section{References}

Allen, J. C. (1966) Amer. F. Ophthal., 62, 509

Berson, D., ZAUberman, H., LANDAU, L., and blumenthal, M. (1969) Ibid., 67, 395

BOlES-CARENIN, B., BUtEN, R. E., SPURGEON, W. M., and ASGHER, K. W. (I955) Ibid., 40, 224

CAIRNS, J. E. (I968) Ibid., 66, 673

DEVOE, A. G. (195I) A.M.A. Arch. Ophthal., 46, 504

FRIEDENWALD, J. s. (1950) Amer. J. Ophthal., 33, 1523

ILIFF, C. E. (1944) Ibid., 27, 73I

LUNTZ, M. H., and SMrTH, R. J. H. (1960) Brit. F. Ophthal., 44, 600

MAUMENEE, A. E. (1967) "Highlights of Ophthalmology", 1966 series (U.S. ed.), vol. 9, p. 36.

Pan-American Institute of Ophthalmology, Panama

McNAIR, s. s. (1951) Amer. J. Ophthal., 34, 70

SCHEIE, H. G. (1962) Ibid., 53, $57 \mathrm{I}$

(1969) "Highlights of Ophthalmology", 1968 series (U.S. ed.), vol. I I, p. 15. Pan-

American Institute of Ophthalmology, Panama

simmons, w. D. (1959) Amer. F. Ophthal., 47, no. 5, pt 2, p. 62

sollom, A. W. (1969) Brit. F. Ophthal., 53, 561

TENG, c. C., CHI, H. H., and KATZin, H. м. (1959) Amer. F. Ophthal., 47, 6

WELSh, N. н. (1969) S. Afr. med. J., 43, 298 